\title{
皮弁壊死への対策
}

一骨付き筋皮弁一

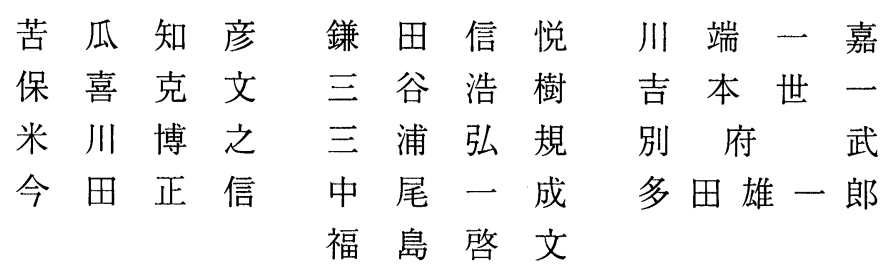

要旨: 癌研病院頭頸科で経験した骨付き筋皮弁による再建手術 74 例をもとに, 皮弁壊死への対策につい て検討した。用いた皮弁は肋骨付き広背筋皮弁が 39 例, 胁骨付き大胸筋皮弁が 18 例, 広背筋抢よび肋 骨付き前鋸筋複合皮弁が 14 例，その他 3 例であった。皮弁の全壞死は 2 例（2.7\%）にみられた。感染な どのために肋骨を除去した症例が 10 例あった。皮弁壊死への対策として，以下の点が重要であると考え た。（1）皮弁採取の際, 肋骨骨膜周辺の微小循環を阻害しない。(2) 再建した骨の周囲に感染を起こさ ない。（3）全壊死の場合は速やかに皮弁を除去し，再手術を考慮する。(4) 再建骨周囲の感染が保存的 に治癒しない場合は骨を除去する。

キーワード：頭頸部癌，再建手術，骨付き筋皮弁，壊死，合併症

\section{Summary Complications after Reconstruction Suegery uaing Bone Compound Musculocutaneous} Flap :

Nigauri T., M.D., Kamata S., M.D., Kawabata K., M.D., Hoki K., M.D., Mitani H., M.D., Yosimoto S., M.D., Yonekawa H., M.D., Miura K., M.D. and Beppu T., M.D. Department of Head and Neck Surgery, Cancer Insttitute Hospital, Tokyo

We reviwed 74 cases of head and neck reconstruction surgery using bone compound musculocutaneous flap, between 1980 and 1997, at our hospital. The tissue used for these reconstructions are as follows; rib-compound latissimus dorsi MC flap for 39 cases, rib compound PMMC flap for 18 cases, latissimus dorsi and rib-compound serratus anteriol MC flap for 14 cases and 3 other flaps. Total flap necrosis was seen in 2 cases $(2.7 \%)$. Due to severe local infection, rib had to be removed in 10 cases. For successful management of bone componud tissue transfer, we have to take care for these points, (1) not to disturb microvascular circulation around the rib, (2) to avoid local infection, (3) to remove the flap immedia tely after total necrosis, (4) sometimes to remove only grafting rib in order to reduce local infection.

Key words : head and neck cancer, reconstruction surgery, bone-compound musculocutaneous flap, flap necrosis, complication.

*癌研究会附属病院頭頸科 
はじめに

頭頸部癌切除後の再建手術の中で, 下顎や上顎 の硬性再建は比較的難度の高い手術である。骨組 織と軟部組織を同時に再建し，場合によっては頸 部の皮䖉まで再建しなければならないような症例 に対しては，骨付き筋皮弁がしばしば用いられて きた。再建手術後の最も深刻な合併症の一つは皮 弁の壊死であるが，骨付き筋皮弁の場合，筋皮弁 と移植骨を両方失うことになると術後の QOL は 大きく低下する。ここでは骨付き筋皮弁の壊死へ の対策について, 癌研究会附属病院頭頸科での経 験をもとに述べる。

\section{対象症例}

癌研究会附属病院頭頸科では, 1980 年から 1997 年の期間に 74 例の骨付き筋皮弁を用いた再 建手術がおこなわれた。皮弁のうちわけは，胁骨 付き広背筋皮弁が 39 例と最も多く，次いで胁骨 付き大胸筋皮弁が 18 例，広背筋および胁骨付き 前鋸筋複合皮弁 14 例，広背筋および肩甲骨複合 皮弁 1 例，肋骨付き腹直筋皮弁 1 例，肋骨付き前 鋸筋弁 1 例であった（表 1 )。これらの症例の性別 は男性 51 例，女性 23 例で平均年齢は 54.9 歳 （29-79歳）であった。疾患別には，口腔癌 49 例 (舌癌 20 例 -下歯肉癌 13 例, 口腔底癌 13 例, 頬 粘膜癌 3 例), 唾液腺癌 10 例（顎下腺癌 7 例, 耳 下線癌 2 例, 舌下腺癌 1 例), 上顎癌 7 例。中咽 頭癌 6 例，その他 2 例（下顎骨肉腫 1 例, 上顎 MFH 1 例）であった（表 2)。74 例中 71 例は術 前に放射線治療を受けており，そのうち 7 例は 70Gy 以上の照射線量であった。74 例中 43 例 （58.1\%）が他院で何らかの治療を受けてから当 科を受診した二次例で，手術後の再発例が 20 例 (27.0\%) 含まれていた。骨の再建部位は下顎骨 66 例，上顎骨 8 例であった。口腔と頸部皮膚を同 時に再建する必要のあった症例は 32 例 $(43.2 \%)$ であった。この内の 14 例には，骨付き筋皮弁の 他にもう一つ別の皮弁（前腕皮弁 9 例，DP 皮弁 4 例，大胸筋皮弁 1 例）を用いた。

\section{結果}

骨付き筋皮弁の全壊死は 74 例中 2 例（2.7\%）
表 1 自験例（癌研病院頭頸科；1980 1997）

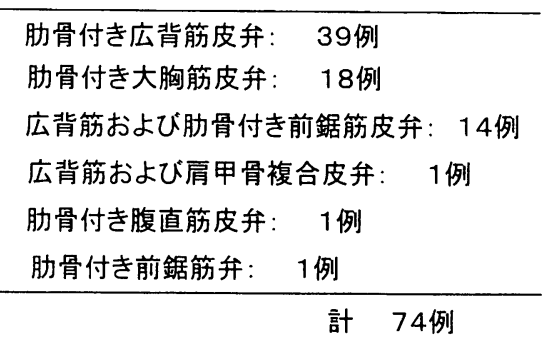

表 2 対象症例の背景

性別：男性:51例、女性: 23例

年歯令：29-79歳、平均 54.9 歳

疾患別頻度: 口腔癌 49 例、唾液腺癌 10 例、 上額癌7例、中咽頭癌6例、その他2例

\begin{tabular}{|c|c|c|}
\hline $\begin{array}{r}\text { 放射線治療 } \\
\text { (手術前) }\end{array}$ & $\begin{array}{l}\text { なし } \\
\sim 40 G y \\
41 \sim 70 G y\end{array}$ & $\begin{array}{l}3 \text { 例 } \\
32 p \\
271\end{array}$ \\
\hline & 71 100Gy & 4例 \\
\hline & 100Gy & 3例 \\
\hline & Ra針 & 3例 \\
\hline
\end{tabular}

二次例 : 43例 $(58.1 \%)$

この内、他院手術後再発例 20 例

骨による再建部位：下顎 66例、上顎8例

口腔、頚皮同時再建例：32例

にみられた。この 2 例の他にもう 1 例皮弁栄養血 管の血流障害を生じたが, 手術翌朝に再吻合して 救済された。創部の感染は 25 例にみられた。こ の内 10 例では，最終的に肋骨を除去せざるを得 なかった。全壊死の 2 例とあわせて 74 例中 12 例 （16.2\%）で肋骨が生着しなかった。他の 15 例の 感染は保存的に治癒した。

\section{皮弁全壊死の 2 例}

症例 $1: 45$ 歳, 男性, 舌癌。89 年 5 月 30 日手 術。胁骨付き広背筋皮弁で再建したが, 壊死。大 胸筋皮弁で再手術をおこなった。原因は静脈血栓 であったが，なぜ血栓を生じたかは不明であった。

症例 $2: 55$ 歳, 男性, 上顎癌。92年 3 月 12 日 手術。胁骨付き腹直筋皮弁で再建したが，壊死。 広背筋皮弁で再手術をおこなった。原因は静脈血 栓であったが，その原因は骨および筋肉による血 管茎の圧迫と推測された。 
表 3 胁骨を除去した 10 例

性別：男性 9例、女性 1例

年齢： $48 \sim 67$ 歳、平均年齢59.7 歳

放射線治療：

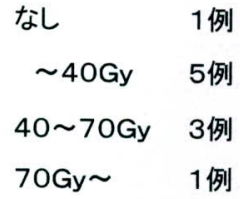

二次例：5/10(50\%)（既手術例1例)

使用皮弁: 肋骨付き広背筋皮弁 4例

胁骨付き大胸筋皮弁 5例

広背筋十肋骨付き前鋸筋皮弁 1例

\section{胁骨を除去した 10 例}

性別は男性 9 例，女性 1 例，平均年齢は 59.7 歳 （48-67歳）であった。10 例中 5 例が二次例であっ た。10 例中 9 例が放射線治療を受けており，5例 は 40Gy 以下, 3 例は 40 70Gy，1 例は 70Gy 以 上であった。このような患者背景からは, 胁骨除 去に至った患者に特徴的な傾向といったものはみ られなかった。再建に用いた皮弁は，胁骨付き広 背筋皮弁 4 例, 胁骨付き大胸筋皮弁 3 例, 胁骨付 き大胸筋皮弁および前腕皮弁 2 例, 広背筋および 胁骨付き前鋸筋複合皮弁 1 例であった（表 3 )。肋 骨付き大胸筋皮弁において, 胁骨を除去する頻度 が高かった（18 例中 5 例：27.7\%)。胁骨を除去 せざるを得なくなった原因は創部の感染，すなわ ち胁骨周囲の感染である。胁骨除去後に感染は消 退した。ただし胁骨自体の血流に問題があって肋 骨が壊死したと確実にいえることはむしろ少なく， 胁骨周囲の感染を保存的に制御できない場合に胁 骨を除去して死腔をつぶす必要があった，または 感染が二次的に胁骨に波及して骨の壊死を起こし たと考えられる。したがって肋骨除去と胁骨壊死 は完全には一致しないが, 今回の検討では広い意 味での皮并壊死の中に含めて考えた。

\section{考察}

頭頸部癌再建手術後の皮弁壊死はきわめて深刻 な合併症である。周囲の感染や大血管の状況によっ ては緊急手術が必要となることもある。時間的に

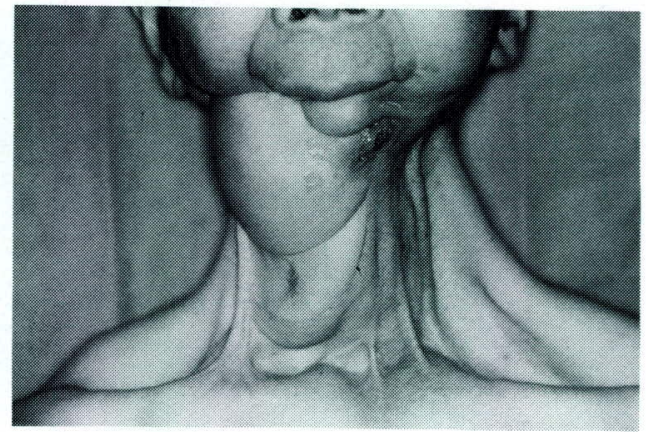

図 1 術後の感染のため移植骨を除去した例。いわ ゆる bird face となり, 機能面, 整容面と もによくない。

多少の猶予があったとしても，再手術では機能の 面でも形態の面でも初回手術より劣ることが多く, 患者の QOL は低下する ${ }^{1 ｝ \text { （図 1）。また，長時間 }$ 手術後の術創のトラブルをきっかけにさらに重篤 な全身合併症を引き起こし, 最悪の結果を招くこ ともある。

皮弁壊死のパターンにはいくつかあるが，骨付 き筋皮弁の場合は，皮弁全壊死，皮弁部分壊死， 骨壊死の 3 つが考えられる。皮弁全壊死は栄養血 管の血流障害によっておこる。部分壊死は, 皮弁 の微小循環不全やデザインミスで起こりうるが, 今回の対象症例の中にはみられなかった。骨のみ の壊死は部分壊死の一種であるが, 骨への血流が 何らかの理由で悪くなれば起こりうる。その原因 としては, 骨周囲の感染のために二次的に起こる 場合と, 皮弁採取時の不適切な操作ではじめから 骨への血流が阻害されている場合がある。骨付き 筋皮弁の場合, 肩甲骨や腸骨のように骨への直接 の栄養枝を含めて骨弁や皮弁を挙上するのではな い。胁骨への栄養は主に骨膜栄養である ${ }^{2)}$ 。した がって, 皮弁採取時から再建術中に至るまで注意 深い扱いが必要である。

（1）再建皮弁の選択

皮弁壊死を防ぐ第一歩は手術適応を誤らないこ とである。患者の全身状態, 腫瘍の進展度に応じ た術式を選択しなければならない。われわれは通 常の下顎再建であれば，現在は肩甲骨皮弁を第一 選択としている ${ }^{3)}$ 。二次例などで上頸部に適当な 血管がなく，より長い血管茎が必要である場合， 下顎亜全摘ないし全摘後の再建でより長い骨が必 


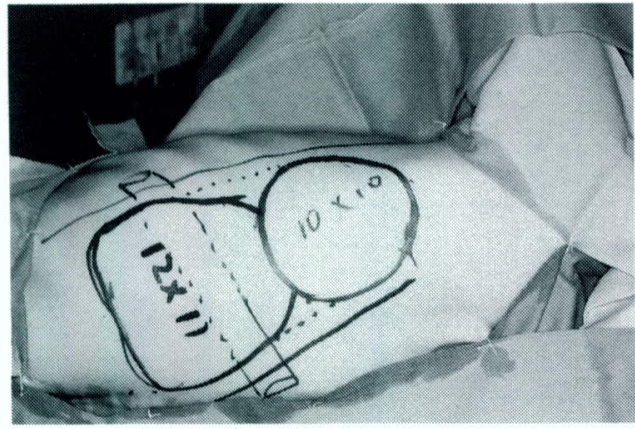

図 2 肋骨付き広背筋皮弁のデザイン。このように 二皮島の皮弁としても用いることができる。

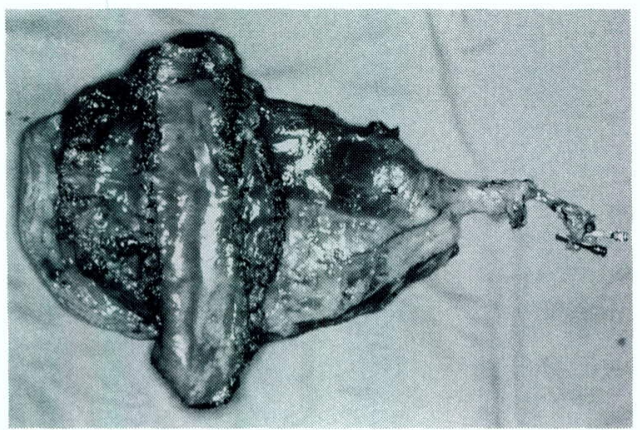

図 3 胁骨付き広背筋皮弁。胁骨側から見る。第 10 胁骨に上下の肋間筋を付けて採取されている。

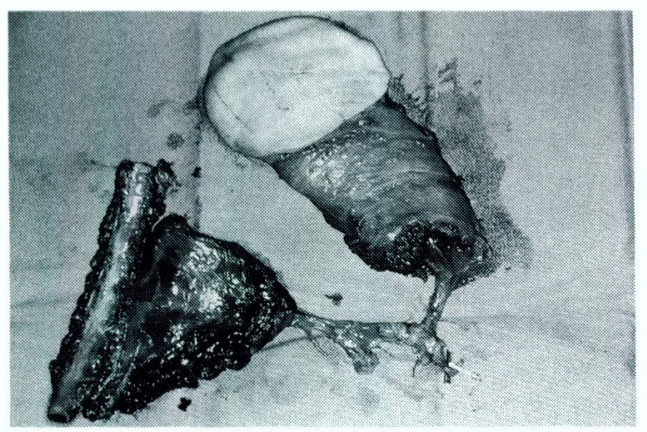

図 4 広背筋および肋骨付き前鋸筋複合皮弁。胸背 動静脈ないし肩甲下動静脈を共通の栄養血管 として挙上する。胁骨の可動性がよい。

要な場合, 頸部皮虐をも含めて再建しなければな らない場合にはしばしば胁骨付き広背筋皮弁を用 いてきた ${ }^{4,5)}$ (図 2,3)。より複雑な三次元的再建 で胁骨の可動性が要求される時には広背筋と肋骨 付き前鋸筋を，胸背動静脈ないし肩甲下動静脈を 栄養血管とする複合皮弁として用いることもでき

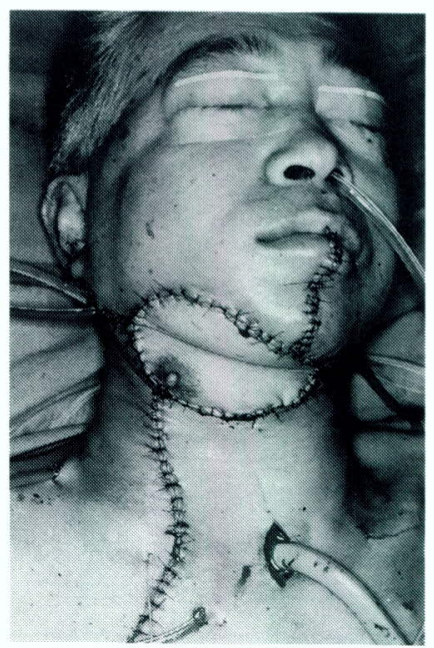

図 5 肋骨付き大胸筋皮弁と前腕皮弁による再建。

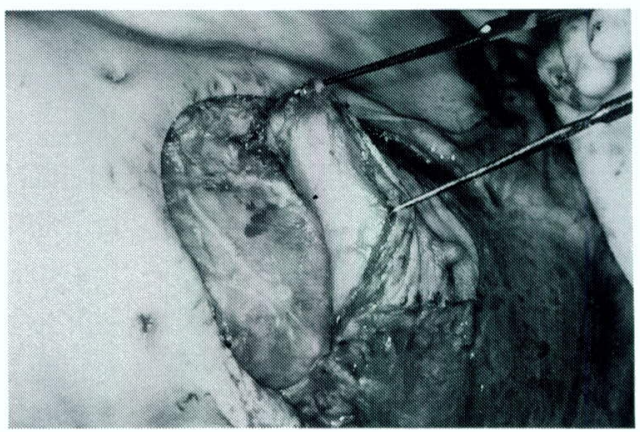

図 6 肋骨付き大胸筋皮弁の挙上。胁骨の上下の肋 間筋，骨膜周囲の結合組織を含め丁寧に操作 する。なるべく開胸にはしない。

る（図 4)。患者の全身状態等からの判断で, 手術 時間の短縮が必要なときは胁骨付き大胸筋皮弁を 選択する ${ }^{6)}$ (図 5)。体位交換をおこなわないこと と血管吻合が必要ないことから 4 時間程度の短縮 が見込める。ただし胁骨への血流という点では広 背筋の方が安定している。

（2）皮弁採取時の注意

次に大切なのは手術中の丁寧な操作である。胁 骨周囲の微小循環を損傷しない様に骨採取時には 十分な注意が必要である。胁骨を採取する際，胸 膜は肋骨につけて採取してもよいが, 胸膜を保存 して開胸しないで皮弁を挙上することも可能であ る。皮弁と骨の間の疎な結合組織を切離しないよ うに，胁骨の場合は上下の肋間筋を付け，前鋸筋 
を付着させたまま皮弁を挙げる（図 6)。

(3) 術中, 術後の注意

3つ目のポイントは感染を起こさないことであ る。再建骨周囲に感染が及ぶと遷延することが多

く，最終的に骨を除去せざるを得なくなることも ある。感染の原因は口腔との漏孔, 術後の血腫, 死腔の存在などが考えられる。これらの点に注溝 して手術をおこなうことが大切と思われる。確実 な血管吻合手技はいうまでも無い。ドレーンの位 置や骨による血管茎の圧迫などにも気を配る必要 がる。

（4）壊死, 感染後の処置

血流障害を早い段階で発見できれば血管を再吻 合して皮弁の全壊死を免れることが可能である。 そのため術後の皮弁の観察には細心の注意を払う べきである。われわれは血流障害を疑ったら，躊 躇せず術創を開いて実際に血管吻合部を確認する ようにしている。吻合部血栓が認められたらその まま顕微鏡下に血栓を除去し再吻合を試みる。

皮弁が完全に壊死に陥った時は速やかに皮弁を 除去するしかない。その結果, 頸動脈が露出する ようであれば緊急手術をおこない何らかの皮弁で 被覆することを考える。ある程度厚みのある筋皮 弁が望ましい。下顎再建は二期的におこなう方が 無難であろう。

皮弁の血流は良好であるにもかかわらず，再建 骨周辺に感染をおこし膿の貯留がみられる場合は, 頸部からドレナージし洗浄する。移植骨に感染が 波及して治癒が遷延するようであれば骨を除去す ることを考慮しなければならない。

\section{まとめ}

骨付き筋皮弁の壊死に対する対策として，以下 の点が重要と考えられた。

（1）皮弁採取の際，骨膜周辺の微小循環を阻害 しないように丁寧に操作する。

（2）再建した骨の周囲に感染を起こさないよう に十分に配慮する。

（3）皮弁全壊死の場合は速やかに皮弁を除去し, 場合によっては緊急手術を抢こなって大血管を被 覆する。

（4）移植骨周囲の感染が保存的に治瘉しない場 合は，骨のみの除去を考慮する。

本論文の要旨は第 10 回日本頭頸部外科学会学術講演 会においてロ演した。

\section{参考文献}

1）苦瓜知彦, 鎌田信悦, 川端一嘉, 他; 頭頸部癌患者

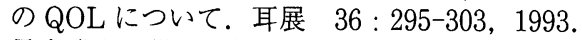

2）足立雅利, 鎌田信悦, 川端一䕒, 他：下顎再建の術 式と術後機能に関する検討. 耳喉頭頸 69:9-13, 1997.

3）丸山 優, 大西 清: 4. 骨付き筋皮弁一（1）肋骨 付き皮弁 : 肋骨広背筋皮弁. 耳喉頭頸 $71: 53-58$, 1999.

4）鎌田信悦, 川端一嘉, 高橋久昭, 他: 肋骨付広背筋 皮弁による下顎の再建. 形成外科 $34: 25-33$, 1991.

5）鎌田信悦, 川端一嘉, 井上哲生：下顎骨区域切除に 対する再建術. JOHNS, 6:303-314, 1990.

6）沼田 勉, 今野昭義, 花沢豊行, 他：4. 骨付き筋 皮弁一（1）胁骨付き皮弁: 肋骨付き大胸筋皮弁の 採取法と下顎再建における利用法一. 耳喉頭頸 71 : 60-66, 1999. 